\section{References}

1. Yan TD, Cao C, Martens-Nielsen J, Padang R, Ng M, Vallely MP, et al. Transcatheter aortic valve implantation for high-risk patients with severe aortic stenosis: a systematic review. J Thorac Cardiovasc Surg. 2009 Oct 19 [Epub ahead of print].

2. Ye J, Cheung A, Lichtenstein SV, Altwegg LA, Wong DR, Carere RG, et al. Transapical transcatheter aortic valve implantation: 1-year outcome in 26 patients. J Thorac Cardiovasc Surg. 2009;137:167-73.

3. Fraccaro C, Napodano M, Tarantini G, Gasparetto V, Gerosa G, Bianco R, et al. Expanding the eligibility for transcatheter aortic valve implantation: the trans- subclavian retrograde approach using the III Generation CoreValve revalving system. JACC Cardiovasc Interv. 2009;2:828-33.

4. Bleiziffer S, Ruge H, Mazzitelli D, Hutter A, Opitz A, Bauernschmitt R, et al. Survival after transapical and transfemoral aortic valve implantation: talking about two different patient populations. J Thorac Cardiovasc Surg. 2009;138: 1073-80.

5. Vendramin I, Piccoli G, Gasperini Livi U. Right minithoracotomy as an alternative approach for endovascular repair of thoracic aortic aneurysm. J Thorac Cardiovasc Surg. 2007;134:1589-91.

\title{
Carinal stabilization technique in severe tracheobronchial malacia after slide tracheoplasty
}

\author{
Igor E. Konstantinov, MD, PhD, Melbourne, Australia
}

Pulmonary artery (PA) sling complex is a spectrum of anomalies that commonly include left PA sling, left ligamentum arteriosum, hypoplastic right lung, and severe long-segment tracheal stenosis. ${ }^{1}$ During the last decade, slide tracheoplasty has become the method of choice in repairing severe longsegment tracheal stenosis. ${ }^{2,3}$ However, fewer than 250 children have undergone slide tracheoplasty worldwide. The operative mortality ranges from $5 \%$ to $33 \%{ }^{2,3} \mathrm{PA}$ sling complex and other concomitant cardiovascular anomalies add to the complexity and risk of slide tracheoplasty. Furthermore, severe tracheobronchial malacia often persists after tracheoplasty, resulting in unstable airways. Collapse at the carina results in an inability to deflate both lungs and is lifethreatening. This report describes a simple technique of carinal stabilization that provided effective relief of carinal collapse in severe tracheobronchial malacia after extensive slide tracheoplasty.

\section{CLINICAL SUMMARY}

A 2-month-old boy (height $52 \mathrm{~cm}$, weight $4 \mathrm{~kg}$ ) presented with severe stridor and respiratory failure. PA sling complex was diagnosed (Figure 1, $A-C$ ), consisting of left PA sling, left ligamentum arteriosum, severe long-segmental tracheal stenosis with complete rings ("rat-tail trachea"), bilateral superior venae cavae, and ventricular septal defect. The

\footnotetext{
From the Cardiac Surgery Unit, Royal Children's Hospital, University of Melbourne, Melbourne, Australia.

Disclosures: None.

Received for publication Jan 13, 2010; accepted for publication Feb 20, 2010; available ahead of print April 12, 2010.

Address for reprints: Igor E. Konstantinov, MD, PhD, Royal Children's Hospital, Flemington Road, Parkville, VIC 6009, Australia (E-mail: igor.konstantinov@rch. org.au).

J Thorac Cardiovasc Surg 2010;140:717-9 $0022-5223 / \$ 36.00$

Crown Copyright (C) 2010 Published by Elsevier Inc. on behalf of The American Association for Thoracic Surgery

doi:10.1016/j.jtcvs.2010.02.031
}

complete rings began at the carina and extended to $5 \mathrm{~cm}$ above the carina, preventing insertion of a $3-\mathrm{mm}$ endotracheal tube. The patient was intubated with a $3.5-\mathrm{mm}$ tube positioned right above the narrowing. The patient underwent urgent surgery via a midline sternotomy with cardiopulmonary bypass (CPB) support. Total CPB time was 228 minutes. Aortic crossclamp time was 40 minutes. In surgery, the left ligamentum arteriosum was divided, the left PA was disconnected and reimplanted into the main PA, the ventricular septal defect was closed with autologous pericardial patch, the carina was mobilized, and extensive slide tracheoplasty was performed. Division of both pulmonary ligaments, incision of the posterior pericardial reflection inferiorly, and hilar release contributed significantly to mobilization of the trachea and allowed extensive tension-free slide tracheoplasty (Figure 2, $A, B$ ). However, severe malacia of the carina and both main bronchi caused air-trapping and an inability to deflate the lungs, necessitating patching of the carina with fresh autologous pericardium and externally stabilizing the carina with a ring-enforced, 8mm polytetrafluoroethylene (Gore-Tex; WL Gore and Associates Inc, Flagstaff, Ariz) (Figures $1, D-F$, and $2 C, D$ ) conduit. Both proximal main bronchi and distal trachea were suspended within the external polytetrafluoroethylene (Gore-Tex) frame with the interrupted sutures. The polytetrafluoroethylene (Gore-Tex) graft was split to allow growth of the airways. The trachea and polytetrafluoroethylene (Gore-Tex) were covered with a pericardial flap, as previously described, ${ }^{4}$ to prevent erosion of these structures into the adjacent vessels. The patient was discharged after a short and uneventful postoperative course. However, he was readmitted 2 months after surgery with stridor and granulation tissue at the carina at the site of the autologous pericardial patch. The granulation tissue was removed by rigid bronchoscopy. The patient did not require intubation for this procedure. He was asymptomatic and doing well 3 months after surgery. 

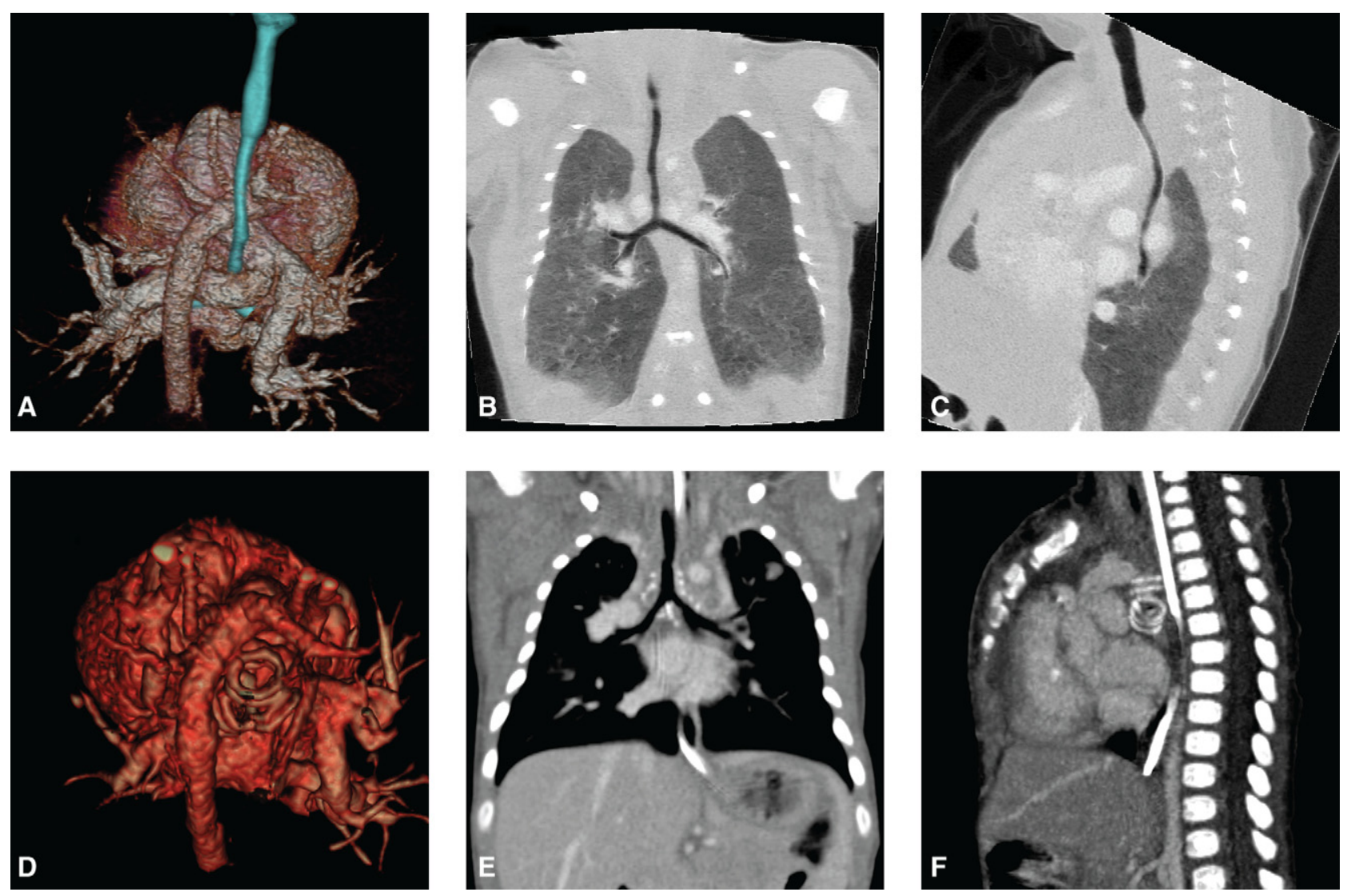

FIGURE 1. Computed tomography scan shows left PA sling (A) with severe long-segmental tracheal stenosis with complete rings ("rat-tail trachea") (A-C) and carinal stabilization with a ring-enforced, 8-mm polytetrafluoroethylene (Gore-Tex; WL Gore and Associates Inc, Flagstaff, Ariz) conduit after slide tracheoplasty (D-F).

\section{DISCUSSION}

Severe long-segmental tracheobronchomalacia at the level of the carina after slide tracheoplasty and removal of external compression by PA sling resulted in carinal collapse with life- threatening respiratory failure, air-trapping, and inability to ventilate the patient. Carinal enlargement with an autologous pericardial patch and external stabilization provided stable airways with dramatic improvement of ventilation. External
A

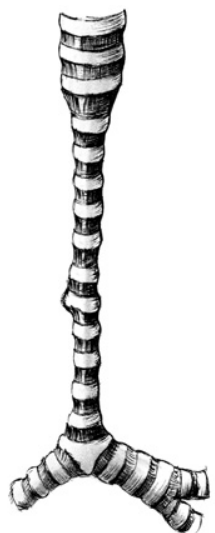

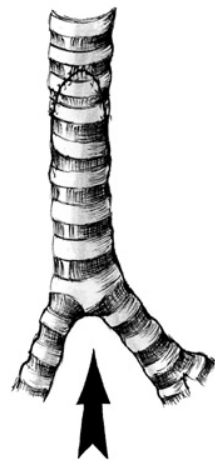

B

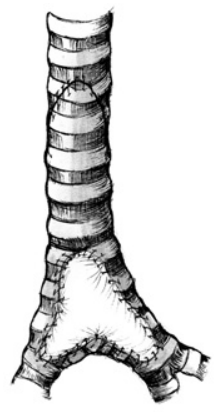

C

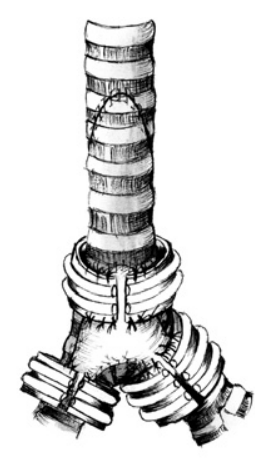

D

FIGURE 2. Schematic diagram of the extent of slide tracheoplasty and carinal stabilization. Extensive narrowing of the trachea consisted of complete rings (A). Slide tracheoplasty shortened the trachea approximately one third of its length and lifted the carina and both left main bronchi (B), exacerbating tracheobronchial malacia at the carina. The collapsed area of the carina and both main bronchi were opened and patched with a fresh autologous pericardial patch (C). The carina was stabilized with split strips of the ring-enforced polytetrafluoroethylene (Gore-Tex) conduit (D). 
stabilization of the long-segmental tracheobronchomalacia has been described. ${ }^{5}$ This report demonstrates that this concept is effective for carinal stabilization.

A recent study of 40 children, 11 of whom had left PA sling, identified preoperative mechanical ventilatory support and duration of CPB to be significant risk factors for prolonged postoperative ventilatory support. ${ }^{2}$ Repair of PA sling complex and other cardiovascular anomalies increases the complexity of surgery and duration of $\mathrm{CPB}$, thus exposing patients to a higher risk of prolonged postoperative ventilatory support. Excessive endotracheal granulation at the site of mechanical irritation by the endotracheal tube often develops in patients with PA sling complex and tracheomalacia, who require prolonged ventilatory support. External stabilization of the carina permitted an uneventful and early extubation in our patient despite prolonged CPB. Covering the trachea with the pericardial flap after tracheoplasty, as previously described, ${ }^{4}$ was helpful in our patient to reinforce the tracheal anastomotic seal, to prevent erosion of the polytetrafluoroethylene (GoreTex) rings into the blood vessels, and to enable safer subsequent bronchoscopic interventions. Potential long-term issues, if any, are yet to be described. The split in the polytetrafluoroethylene (Gore-Tex) rings should allow normal growth, and the pericardial flap will prevent erosion of the rings into the adjacent vessels.

\section{CONCLUSIONS}

This simple technique of carinal stabilization immediately stabilizes airways and can be lifesaving in patients with severe long-segmental stenosis after tracheoplasty.

\section{References}

1. Chen SJ, Lee WJ, Lin MT, Wang JK, Chang CI, Chiu IS, et al. Left pulmonary artery sling complex: computed tomography and hypothesis of embryogenesis. Ann Thorac Surg. 2007;84:1645-50.

2. Manning PB, Rutter MJ, Border WL. Slide tracheoplasty in infants and children risk factors for prolonged postoperative ventilatory support. Ann Thorac Surg. 2008;85:1187-91.

3. Elliott M, Hartley BE, Wallis C, Roebuck D. Slide tracheoplasty. Curr Opin Otolaryngol Head Neck Surg. 2008;16:75-82.

4. Konstantinov IE. d'Udekem Y, Saxena P. Interposition pericardial flap after slide tracheoplasty in pulmonary artery sling complex. Ann Thorac Surg. 2010;89: 289-91

5. Hagl S, Jakob H, Sebening C, et al. External stabilization of long-segment tracheobronchomalacia guided by intraoperative bronchoscopy. Ann Thorac Surg. 1997; 64:1412-21.

\title{
Aortic valve replacement and coronary artery bypass via left anterior thoracotomy after previous left pneumonectomy
}

\author{
Sotiris C. Stamou, MD, Michael C. Murphy, MD, and Nicholas T. Kouchoukos, MD, St Louis, Mo
}

Left anterior thoracotomy is an infrequent approach to perform open cardiac operations. It has been used for coronary artery bypass grafting $(\mathrm{CABG})$ and rarely for valvular procedures. ${ }^{1-4}$ We describe a left anterior thoracotomy approach for combined aortic valve replacement (AVR) and myocardial revascularization in a patient with a marked shift of mediastinal structures after previous left pneumonectomy.

\footnotetext{
From the Division of Thoracic and Cardiovascular Surgery, Missouri Baptist Medical Center, St Louis, Mo.

Disclosures: None.

Received for publication Dec 23, 2009; accepted for publication Jan 3, 2010; available ahead of print March 26, 2010.

Address for reprints: Nicholas T. Kouchoukos, MD, 3009 N. Ballas Road, Suite 266C, St Louis, MO 63131 (E-mail: NTKouch@aol.com). or Sotiris C. Stamou, MD, 1315 Whispering Pines Dr, Apt L, St Louis, MO 63146 (E-mail: cvsisfun@hotmail.com). J Thorac Cardiovasc Surg 2010;140:719-20 $0022-5223 / \$ 36.00$

Copyright (c) 2010 by The American Association for Thoracic Surgery doi:10.1016/j.jtcvs.2010.01.019
}

\section{CLINICAL SUMMARY}

An 83-year-old man presented with frequent episodes of chest pain and shortness of breath. He had undergone a left pneumonectomy for a T4 N2 M1 poorly differentiated adenocarcinoma of the left lung 8 years previously and subsequent stenting of the left anterior descending and circumflex coronary arteries. Transthoracic echocardiography and cardiac catheterization demonstrated severe stenosis of the left main and right coronary arteries, severe aortic stenosis, and moderate aortic regurgitation. Computed tomography of the chest revealed marked displacement of mediastinal structures into the left side of the chest (Figure 1). His pulmonary function tests included a forced expiratory volume at 1 second $48 \%$ of predicted and carbon monoxide diffusion in the lung $77 \%$ of predicted. Operation was recommended.

Given the patient's anatomy, a left anterolateral thoracotomy approach was selected. The patient was placed supine with the left hemithorax elevated 30 degrees. Left axillary artery and right common femoral artery cannulation were 